\title{
Model aplikasi cybercounseling Islami berbasis website untuk meningkatkan self-regulated learning siswa SMA
}

\author{
Eni Fariyatul Fahyuni *, Dzulfikar Akbar, Nurul Hadi, Mochammad Imron Haris, Nur \\ Kholifah \\ Fakultas Agama Islam, Universitas Muhammadiyah Sidoarjo. \\ Jl. Mojopahit No. 666 B, Sidowayah, Celep, Sidoarjo, Jawa Timur 61215, Indonesia. \\ eni.fariyatul@umsida.ac.id \\ * Corresponding Author
}

\section{ARTICLE INFO}

\section{Article History}

Received:

2 September 2020;

Revised:

14 October 2020;

Accepted:

21 October 2020

Keywords

Model bimbingan

konseling;

Cybercounseling;

Self-regulated

learning;

The counseling model;

Website

\begin{abstract}
Penelitian ini merupakan jenis penelitian dan pengembangan yang bertujuan untuk mengembangkan model aplikasi cybercounseling Islami berbasis website guna membantu memaksimalkan self-regulated learning siswa melalui layanan bimbingan dan konseling berbasis cyber pada era pendemi Covid-19. Jenis penelitian pengembangan ini mengacu pada model Dick, Carey, dan Carey yang terdiri atas 10 tahapan. Hasil penilaian validasi oleh beberapa tim ahli pada model layanan bimbingan konseling melalui cybercounseling berbasis website didapatkan nilai rerata adalah 3,78. Ujicoba individu skor yang dihasilkan sebesar 3,86 dan ujicoba kelompok terbatas skor yang didapat sebesar 3,86. Berdasarkan hasil penilaian tersebut dapat disimpulkan bahwa model layanan bimbingan konseling melalui cybercounseling berbasis website yang dikembangkan dalam kategori sangat layak digunakan sebagai model layanan bimbingan konseling berbasis digital. Dengan demikian model layanan bimbingan konseling melalui cybercounseling berbasis website yang dikembangkan terbukti efektif mampu meningkatkan self-regulated learning yang dapat membantu siswa memfokuskan pencapaian pada tujuan pembelajaran, mengontrol proses pembelajaran, menumbuhkan motivasi sendiri, dan membangun kepercayaan diri guna mendukung serta optimalisasi proses pembelajaran.
\end{abstract}

This research is a type of research and development which aims to develop a webbased Islamic cybercounseling application model to help maximize student selfregulated learning through cyber-based guidance and counseling services in the COVID-19 pandemic era. This type of development research refers to the Dick, Carey, and Carey model which consists of over 10 stages. The valid production results by several expert teams of counseling service models through web-based cybercounseling, the mean value of search was 3.78. Individuals with the resulting test score of 3.86 and the limited trial group the score obtained was 3.86. Based on the results of this assessment, the guidance can state that the counseling service model through web-based cyber-counseling developed in the category is very suitable for use as a digital-based counseling model. Thus the counseling service model through web-based cybercounseling that has been developed has proven to be effective in improving self-regulated learning which can help students focus on learning goals, control the learning process, foster self-motivation, and build self-confidence to support and optimize the learning process.

This is an open access article under the $\underline{\mathrm{CC}-\mathrm{BY}-\mathrm{SA}}$ license.

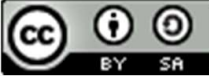




\section{PENDAHULUAN}

Dunia saat ini sedang dilanda merebaknya wabah virus corona atau yang disebut dengan Covid-19. Coronavirus berdampak pada semua aspek kehidupan, terutama bidang pendidikan. Siswa pada jenjang sekolah menengah atas harus dapat mengelola belajarnya secara optimal walaupun ditengah mewabahnya pandemi Covid-19. Fungsi sekolah sebelum mewabahnya Covid-19 adalah menjadi tempat bertemu dan berprosesnya pembelajaran yang berpusat pada belajar siswa (Bahiyah, Sudarmin, \& Hartono, 2019). Siswa membangun self regulated learning merupakan suatu hal terpenting guna menghindarkan dari perilaku prokrastinasi akademik yang disebabkan kejenuhan selama proses belajar daring atau online di masa pandemi Covid-19. Hasil penelitian menunjukkan bahwa self regulated learning terbukti efektif meningkatkan kepercayaan diri siswa (Aliem, Sugiharto, \& Awalya, 2020). Dengan demikian dampak Covid-19 di Indonesia menuntut inovasi dan kesiapan guru dan siswa menggunakan teknologi digital dengan layanan yang mengutamakan keamanan, kenyamanan, dan privasi siswa (Atif, Mathew, \& Lakas, 2014), yang memaksimalkan kolaborasi layanan guru pendidikan agama Islam, guru kelas, dan konselor BK (Rahayu, 2019) untuk mempermudah akses layanan kepada para siswanya tanpa batas jarak, ruang, dan waktu (Petrus \& Sudibyo, 2017).

Seiring kemajuan teknologi pada abad ke-21 yang menuntut pendidik untuk dapat beradaptasi dengan teknologi berbasis digital. Hasil survey Asosiasi Penyelenggara Jasa Internet Indonesia (APJI) pada tahun 2017 bahawa dari total penduduk Indonesia 262 juta jiwa, hampir setengahnya yakni 143,26 juta jiwa atau 54, 68\% adalah pengguna internet. Pengguna masyarakat Indonesia pada tingkat Internasional menempati peringkat ke-5 setelah Tiongkok, India, USA, dan Brazil. Seiring dengan pesatnya perkembangan internet menuntut sistem layanan bimbingan konseling di sekolah juga harus mulai berbenah menyesuaikan perkembangan teknologi informasi saat ini (Sutijono \& Farid, 2018). Untuk itu sekolah perlu mendesain dan melakukan inovasi pembelajaran didalamnya (Nikolov, Shoikova, Krumova, Kovatcheva, Dimitrov, \& Shikalanov, 2016) yang berbasis teknologi digital (Sari, Ciptadi, \& Hardyanto, 2017). Layanan bimbingan konseling berbasis digital terbukti efektif meningkatkan performansi siswa (Hernawati, Sugiarto, Purwanto, \& Awalya, 2018).

Sekolah memegang peranan penting dalam membangun dan memaksimalkan kompetensi para siswanya. Hal ini dikarenakan tugas siswa di sekolah tidak hanya belajar dan berfikir, namun siswa adalah makhluk hidup yang mempunyai keinginan, kebutuhan, dan karakter yang berbeda-beda. Hal ini dikarenakan keberadaan siswa di sekolah yang tidak terlepas dari berbagai permasalahan yang harus mereka hadapi. Salah satu permasalahan yang seringkali terjadi adalah rendahnya kontrol diri siswa pada kegiatan belajar daring saat ini, dimana siswa malas mengerjakan tugas-tugas yang diberikan oleh guru, siswa merasa bosan belajar di rumah saja, dan bahkan siswa terkesan menyepelehkan wabah penyebaran Covid-19 (Purwanto, Pramono, Asbari, Hyun, Wijayanti, \& Putri, 2020). Beragam permasalahan inilah sesungguhnya yang diperlukan peserta didik untuk mampu membangun self-regulated learning dalam dirinya. Self-regulated siswa sangat penting guna meningkatkan kemampuan siswa untuk mengontrol, memilah, dan menerapkan pengambilan keputusannya secara bijak dan bertanggung-jawab. Self-regulated learning merupakan suatu hal terpenting yang perlu dikembangkan oleh siswa guna menghindarkan dari perilaku prokrastinasi akademik yang disebabkan oleh kejenuhan dalam mengerjakan banyaknya tugas yang diberikan, sehingga dapat mempengaruhi rendahnya hasil belajar siswa. Faktor pendidikan atau budaya mampu mempengaruhi karakter dan terbentuknya self-regulated pada diri siswa (Rosito, 2018).

Realitas permasalahan yang terjadi di sekolah adalah sistem layanan bimbingan konseling masih bersifat konvensional (face to face). Utamanya di masa pandemi Covid-19 tentu saja layanan bimbingan dan konseling konvensional ini berjalan stagnan karena siswa kesulitan dalam mengakses untuk berkonsultasi bertatap muka dengan guru bimbingan konseling di sekolah. Keberadaan dan peran guru bimbingan konseling di sekolah saat ini pun masih sebatas sebagai polisi siswa yang tugas dan perannya hanya memberikan hukuman dan menasehati para siswanya jika terlibat dalam permasalahan seperti kekerasan remaja atau tawuran, minum-minuman keras, mencuri, dan sebagainya. Sedangkan bagi siswa-siswa yang berprestasi dengan beragam potensi yang dimiliki, mereka ini belum mendapat layanan yang sesuai dengan kebutuhannya misal layanan untuk dapat mengetahui gaya belajarnya, kecerdasan majemuk untuk mengetahui potensi belajarnya, dan lain sebagai- 
nya dalam rangka membantu memahamkan potensi yang dimiliki kaitannya dengan studi lanjut maupun karier yang akan dijalaninya.

Tujuan dikembangkannya model aplikasi cybercounseling Islami berbasis website adalah untuk membantu memaksimalkan self-regulated learning siswa melalui layanan bimbingan dan konseling berbasis cyber pada era pendemi Covid-19. Hasil penelitian menunjukkan bahwa selfregulated learning yang dimiliki dapat membantu siswa dalam memfokuskan pada pencapaian pada tujuan pembelajaran, mengontrol proses pembelajaran, menumbuhkan motivasi sendiri, dan membangun kepercayaan diri guna mendukung serta optimalisasi proses pembelajaran (Aliem \& Yuwono, 2020). Berdasarkan beberapa hasil survey pada model layanan bimbingan dan konseling di SMA Kabupaten Sidoarjo menyisahkan beberapa persoalan, antara lain: 1.) Rasio jumlah guru bimbingan dan konseling dengan peserta didik yang masih di bawah ideal; 2.) Rendahnya minat siswa mengikuti layanan bimbingan konseling secara face to face; dan 3.) Belum tersedianya layanan bimbingan dan konseling berbasis digital guna menjawab kebutuhan peserta didik di era Covid-19. Dampak dari berbagai permasalahan terkait belum optimalnya model layanan bimbingan dan konseling di sekolah-sekolah kabupaten Sidoarjo tersebut utamanya pada masa pandemi Covid-19, maka diperlukan inovasi guna optimalisasi siswa dalam mendapatkan layanan bimbingan konseling sesuai kebutuhan para siswanya masing-masing. Layanan bimbingan konseling seharusnya merujuk pada pengembangan kurikulum yang ditetapkan guna meningkatkan critical thinking, communication, collaboration, dan creativity peserta didiknya (Purwadhi, 2019).

Untuk itu optimalisasi layanan bimbingan dan konseling melalui cybercounseling berbasis website bagi siswa SMA menjadi sebuah prioritas yang tidak bisa dihindarkan untuk meningkatkan performansi siswa (Hernawati, Sugiarto, Purwanto, \& Awalya, 2018). Pengembangan model aplikasi cybercounseling Islami berbasis website ini menjawab permasalahan akibat dampak Covid-19 yang menuntut guru harus melakukan inovasi layanan bimbingan konseling Islami berbasis teknologi digital yang dapat memberikan keamanan, kenyamanan, dan menjaga privasi (kerahasiaan) permasalahan yang dihadapi siswa dengan siswa lainnya. Pengembangan model layanan bimbingan konseling melalui cybercounseling berbasis website bagi siswa SMA ini diharapkan dapat mengoptimalkan layanan bimbingan konseling yang bertujuan membantu mengatasi permasalahan pribadi, sosial, belajar, dan karier siswa dalam rangka membantu memahamkan potensi yang dimiliki kaitannya dengan studi lanjut maupun karier yang akan dijalaninya. Kebaruan dari pengembangan model aplikasi cybercounseling Islami berbasis website merupakan sarana efektif dalam mengatasi permasalahan siswa dan membangun self regulated learning siswa SMA yang didasarkan pada pedoman Al-Quran dan Hadist pada masa pandemi Covid-19 agar siswa mampu menjalani kehidupannya dengan penuh percaya diri dan mencapai kebahagiaan dunia dan akhirat sesuai dengan ketentuan Allah SWT. Adapun permasalahan penelitian adalah bagaimana mengembangkan prototype model layanan cybercounseling berbasis website guna memaksimalkan self-regulated learning siswa SMA Muhammadiyah 1 Taman Kabupaten Sidoarjo?.

\section{METODE}

Jenis penelitian ini adalah penelitian dan pengembangan (Research and Development) yang mengacu pada model pengembangan menurut Dick, Carey, dan Carey (2009). Jenis penelitian dan pengem-bangan $(R \& D)$ merupakan metode penelitian yang digunakan untuk menghasilkan dan menguji keefektivan produk tertentu. Penelitian dan pengembangan adalah sebuah proses yang digunakan dalam mengembangkan dan memvalidasi produk dimana temuan hasil penelitian digunakan untuk merancang produk dan prosedur yang secara sistematis diuji, dievaluasi, dan direvisi hingga memenuhi kriteria efektivitas, kualitas, atau standar yang telah ditentukan untuk membantu memaksimalkan layanan bimbingan konseling Islami siswa SMA Muhammadiyah 1 Taman-Sidoarjo.

Instrumen penelitian yang digunakan pada penelitian ini adalah angket penilaian kelayakan produk yang diberikan kepada tim ahli dan siswa sebagai calon pengguna dalam skala terbatas. Intrumen angket menilai secara kualitataif dan kuantitaif produk yang dikembangkan menyangkut materi atau konten, konstruksi, dan sosial budaya. Penilaian dalam bentuk kuantitatif akan diprosentasekan untuk mengetahui nilai kumulatif pada kelayakan produk, sedangkan penilaian 
bentuk kualitatif berupa deskripsi saran dan masukan yang diberikan oleh tim ahli maupun calon pengguna. Hal ini sangat diperlukan peneliti guna penyempurnaan produk akhir sesuai dengan saran dan masukan yang diberikan selama proses pengembangan produk. Kriteria penilaian validasi instrumen dapat dilihat pada Tabel 1.

Tabel 1. Kriteria Penilaian Validasi Instrumen

\begin{tabular}{cccc}
\hline \multicolumn{2}{c}{ Intervensi Skor } & Kategori Penilaian & Keterangan \\
\hline 3,60 & $\leq \mathrm{P}<4,00$ & Sangat valid & Tanpa revisi \\
2,60 & $\leq \mathrm{P}<3,50$ & Valid & Revisi kecil \\
1,60 & $\leq \mathrm{P}<2,50$ & Kurang valid & Revisi banyak \\
1,00 & $\leq \mathrm{P}<1,50$ & Tidak valid & Tidak dapat digunakan \\
\hline
\end{tabular}

Populasi penelitian ini adalah siswa SMA Muhammadiyah 1 Taman dengan subyek penelitian siswa kelas $X$ yang memiliki karakteristik antara lain: 1.) Siswa dengan nilai akademik terendah dibandingkan dengan kelas lainnya; 2.) Siswa dengan status pekerjaan orang tua berada pada level menengah ke bawah; dan 3.) Siswa yang memiliki kemudahan akses internet maupun perangkat seluler yang digunakan, seperti smartphone dan yang lainnya. Pengujian produk berupa model layanan bimbingan konseling melalui cybercounseling berbasis website melalui beberapa tahapan, yakni melibatkan validasi beberapa tim ahli, ujicoba produk untuk individu dengan melibatkan 3 siswa dengan level akademik tinggi, rendah, dan sedang. Selanjutnya, uji produk untuk kelompok kecil sebanyak 8 siswa kelas X yang bertujuan untuk mengukur keefektifan produk yang dikembangkan dalam meningkatkan self-regulated learning siswa SMA Muhammadiyah 1 Taman utamanya pada masa pandemic Covid-19. Pengembangan produk berupa model aplikasi cybercounseling Islami berbasis website yang mengacu pada pendekatan sistem model Dick, Carey, dan Carey (2009) yang terdiri atas 10 tahapan yang dapat dilihat pada Gambar 1.

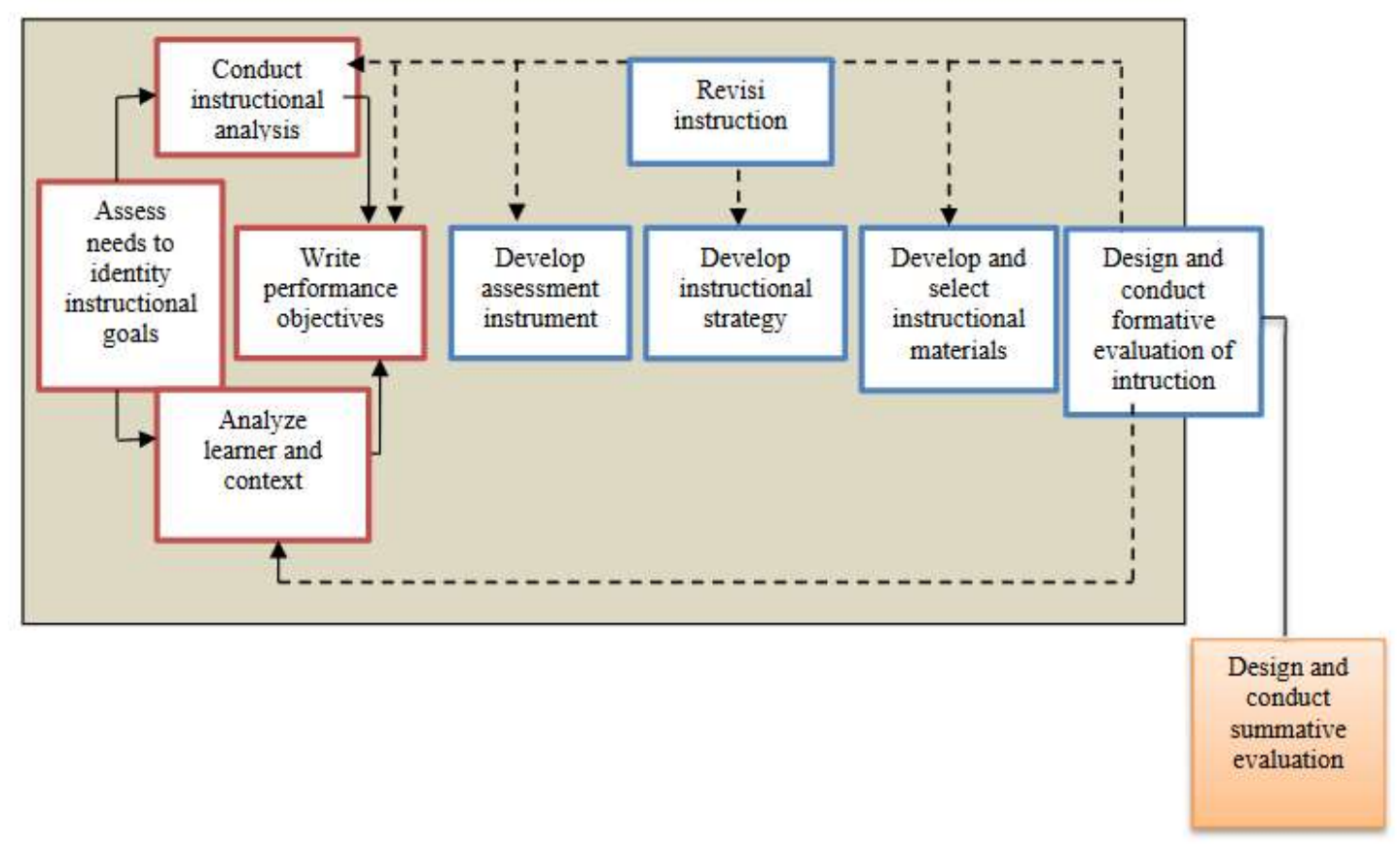

Gambar 1. Desain Pengembangan Model (Dick, Carey, \& Carey, 2009) 


\section{HASIL DAN PEMBAHASAN}

\section{Lingkungan Belajar Smart Berbasis Layanan Cybercounseling}

Hasil analisa pengujian produk berupa model layanan bimbingan konseling melalui cybercounseling berbasis website terdiri atas beberapa tahapan yakni: 1.) Melibatkan validasi dari 3 tim ahli yang terdiri dari 1 ahli dibidang media dan teknologi pembelajaran, 1 ahli dibidang bimbingan dan konseling, dan 1 praktisi yakni dengan melibatkan guru bimbingan konseling di SMA Muhammadiyah 1 Taman Kabupaten Sidoarjo. Hasil penilaian validasi ahli dapat dilihat pada Tabel 2.

Tabel 2. Hasil Penilaian Validasi Ahli

\begin{tabular}{|c|c|c|c|c|}
\hline \multirow{2}{*}{ No. } & \multirow{2}{*}{ Aspek yang Dinilai } & \multicolumn{3}{|c|}{ Penilaian Validator } \\
\hline & & V1 & $\mathrm{V} 2$ & $\mathrm{~V} 3$ \\
\hline \multicolumn{5}{|c|}{ A. Materi } \\
\hline 1 & $\begin{array}{l}\text { Intrumen bimbingan konseling yang digunakan mampu } \\
\text { mengukur potensi belajar siswa }\end{array}$ & 4 & 4 & 3 \\
\hline 2 & $\begin{array}{l}\text { Intrumen bimbingan konseling yang digunakan mampu } \\
\text { memetakan potensi belajar siswa }\end{array}$ & 3 & 3 & 4 \\
\hline 3 & $\begin{array}{l}\text { Intrumen bimbingan konseling yang digunakan } \\
\text { memudahkan siswa mengenali gaya belajarnya }\end{array}$ & 3 & 4 & 3 \\
\hline 4 & $\begin{array}{l}\text { Intrumen bimbingan konseling yang digunakan } \\
\text { memudahkan siswa mengenali kecerdasan majemuknya }\end{array}$ & 4 & 4 & 4 \\
\hline \multicolumn{5}{|c|}{ B. Konstruksi } \\
\hline 1 & Instrumen soal dirumuskan dengan kalimat singkat dan jelas & 4 & 3 & 4 \\
\hline 2 & $\begin{array}{l}\text { Instrumen soal merupakan pernyataan yang diperlukan } \\
\text { saja }\end{array}$ & 4 & 4 & 4 \\
\hline 3 & Terdapat skoring hasil akhir & 3 & 4 & 4 \\
\hline 4 & Skor penilaian akhir disajikan dalam bentuk grafik & 4 & 4 & 3 \\
\hline \multicolumn{5}{|c|}{ C. Bahasa/Budaya } \\
\hline 1 & Butir soal mnggunakan bahasa yang baku & 4 & 4 & 4 \\
\hline 2 & Instrumen soal bersifat komunikatif & 4 & 3 & 4 \\
\hline 3 & Tidak menggunakan kata/ungkapan bermakna ganda. & 3 & 4 & 4 \\
\hline 4 & Tidak menggunakan bahasa yang berlaku setempat/tabu. & 4 & 4 & 3 \\
\hline & Nilai Rerata Total Aspek & 3,75 & $\begin{array}{c}3,83 \\
3,78\end{array}$ & 3,75 \\
\hline
\end{tabular}

Berdasarkan hasil penilaian validasi oleh beberapa tim ahli pada model layanan bimbingan konseling melalui cybercounseling berbasis website didapatkan nilai rerata adalah 3,78. Dengan demikian hasil evaluasi individu oleh 3 tim validator yang dapat dilihat pada Tabel 2 menunjukkan bahwa model layanan bimbingan konseling melalui cybercounseling berbasis website yang dikembangkan adalah dalam kategori sangat layak digunakan sebagai model layanan bimbingan konseling berbasis digital. Oleh karenanya, membangun lingkungan belajar di sekolah yang smart penting dilakukan berupa inovasi pembelajaran pada era millennial yang bertujuan mengoptimalkan hasil belajar siswanya. Siswa di sekolah tidak hanya dipandang sebagai makhluk rasional yang setiap hari tugasnya hanya belajar dan berfikir, namun siswa sebagai makhluk yang mempunyai minat atau keinginan, serta karakter yang berbeda-beda yang terkadang tidak mampu menyelesaikan permasalahan dirinya dan membutuhkan bantuan, arahan, serta pegangan hidup sehingga berdampak pada kesuksesan siswa dalam belajar (Spector, 2016).

Dalam proses pendidikan di sekolah, peran guru memegang peranan sangat penting dalam mensukseskan kegiatan belajar dan mengajarnya. Penanaman nilai-nilai karakter religius pada siswa 
dengan memberlakukan budaya atau kebiasaan yang sesuai dengan tuntunan Islam. Budaya Islami yang dilaksanakan bertujuan untuk membentuk dan meningkatkan moralitas dan karakter religius siswa di sekolah. Peningkatan karakter religius siswa ditandai dengan adanya peningkatan spiritualitas individual dan spiritualitas sosialnya (Marzuki \& Haq, 2018). Hasil penelitian menunjukkan bahwa layanan bimbingan konseling dengan pendekatan nilai-nilai Islam efektif dalam meningkatkan tanggung jawab personal, sosial, dan moral sebesar 22\%. Dengan bimbingan konseling berbasis nilai-nilai Islam dapat melatih siswa belajar mengatur dirinya sendiri, mengontrol, dan mengevaluasi hasil belajarnya sesuai dengan target yang telah ditentukan. Pemberian layanan bimbingan konseling berbasis nilai-nilai ajaran Islam dapat meningkatkan karakter tanggung jawab siswa (Surtiyoni, 2018).

Hasil analisa pengujian produk berupa model layanan bimbingan konseling melalui cybercounseling berbasis website dilakukan pada uji individu dengan melibatkan 3 orang siswa dengan kemampuan akademik tinggi, sedang, dan rendah pada siswa kelas X SMA Muhammadiyah 1 Taman Kabupaten Sidoarjo. Hasil penilaian uji individu dapat dilihat pada Tabel 3.

Tabel 3. Hasil Penilaian Uji Individu

\begin{tabular}{|c|c|c|c|c|}
\hline \multirow{2}{*}{ No. } & \multirow{2}{*}{ Aspek yang Dinilai } & \multicolumn{3}{|c|}{ Penilaian Siswa } \\
\hline & & S1 & S2 & $\mathrm{S} 3$ \\
\hline \multicolumn{5}{|l|}{ A. Materi } \\
\hline 1 & $\begin{array}{l}\text { Intrumen bimbingan konseling yang digunakan mampu } \\
\text { mengukur potensi belajar siswa }\end{array}$ & 4 & 4 & 4 \\
\hline 2 & $\begin{array}{l}\text { Intrumen bimbingan konseling yang digunakan mampu } \\
\text { memetakan potensi belajar siswa }\end{array}$ & 4 & 4 & 4 \\
\hline 3 & $\begin{array}{l}\text { Intrumen bimbingan konseling yang digunakan } \\
\text { memudahkan siswa mengenali gaya belajarnya }\end{array}$ & 4 & 4 & 4 \\
\hline 4 & $\begin{array}{l}\text { Intrumen bimbingan konseling yang digunakan } \\
\text { memudahkan siswa mengenali kecerdasan majemuknya }\end{array}$ & 4 & 4 & 4 \\
\hline \multicolumn{5}{|c|}{ B. Konstruksi } \\
\hline 1 & $\begin{array}{l}\text { Instrumen soal dirumuskan dengan kalimat singkat dan } \\
\text { jelas }\end{array}$ & 4 & 3 & 4 \\
\hline 2 & $\begin{array}{l}\text { Instrumen soal merupakan pernyataan yang diperlukan } \\
\text { saja }\end{array}$ & 4 & 4 & 4 \\
\hline 3 & Terdapat skoring hasil akhir & 3 & 4 & 4 \\
\hline 4 & Skor penilaian akhir disajikan dalam bentuk grafik & 4 & 4 & 3 \\
\hline \multicolumn{5}{|c|}{ C. Bahasa/Budaya } \\
\hline 1 & Butir soal mnggunakan bahasa yang baku & 4 & 4 & 4 \\
\hline 2 & Instrumen soal bersifat komunikatif & 4 & 3 & 4 \\
\hline 3 & Tidak menggunakan kata/ungkapan bermakna ganda. & 3 & 4 & 4 \\
\hline 4 & Tidak menggunakan bahasa yang berlaku setempat/tabu. & 4 & 4 & 3 \\
\hline & Nilai Rerata Total Aspek & 3,83 & $\begin{array}{l}3,83 \\
3,86\end{array}$ & 3,92 \\
\hline
\end{tabular}

Berdasarkan hasil penilaian uji individu oleh 3 siswa pada model layanan bimbingan konseling melalui cybercounseling berbasis website didapatkan nilai rerata adalah sebesar 3,86. Dengan demikian hasil evaluasi individu oleh 3 siswa yang dapat dilihat pada Tabel 3 menunjukkan bahwa model layanan bimbingan konseling melalui cybercounseling berbasis website yang dikembangkan adalah dalam kategori sangat layak digunakan sebagai model layanan bimbingan konseling berbasis digital.

Layanan bimbingan dan konseling memegang peranan penting bagi optimalsasi potensi siswanya (Fahyuni, 2018). Namun layanan bimbingan dan konseling ini belum bersinergi dengan 
mata pelajaran lainnya seperti pendidikan agama Islam yang dapat membantu para siswanya mengarahkan perilakunya ke arah yang lebih baik sesuai tuntunan agama yang diajarkan. Untuk itu pada penelitian selanjutnya perlu diintegrasikan antara program layanan bimbingan konseling dengan beberapa mata pelajaran sekolah, sehingga berbagai permasalahan peserta didik dapat terfasilitasi dengan baik di sekolah. Hal ini dikarenakan inovasi sekolah yang smart di era millennial saat ini adalah dibutuhkan: 1.) Sekolah yang memberikan keleluasaan siswanya pada learning by doing; dan 2.) Sekolah yang melatih kemampuan siswa pada problem solving (Haryani, Masfufah, Wijayati, \& Kurniawan, 2018) yang berbasis cybercounseling untuk mendukung kemudahan akses, serta menjaga privasi klien (Zainudin \& Yusof, 2018), sehingga dapat meningkatkan performansi siswa. Lingkungan belajar yang smart dapat memberikan akses informasi yang lebih mudah dan cepat pada siswanya melalui perangkat yang terkoneksi dengan Internet of Things (IOT) (Chan \& Chan, 2018). Hasil penilaian uji kelompok terbatas dapat dilihat pada Tabel 4.

Tabel 4. Hasil Penilaian Uji Kelompok Terbatas

\begin{tabular}{|c|c|c|c|c|c|c|c|}
\hline \multirow{2}{*}{ No. } & \multirow{2}{*}{ Aspek yang Dinilai } & \multicolumn{6}{|c|}{ Penilaian Siswa } \\
\hline & & $\mathrm{S} 1$ & $\mathrm{~S} 2$ & S3 & S4 & S5 & S6 \\
\hline \multicolumn{8}{|l|}{ A. Materi } \\
\hline 1 & $\begin{array}{l}\text { Intrumen bimbingan konseling yang digunakan } \\
\text { mampu mengukur potensi belajar siswa }\end{array}$ & 4 & 4 & 4 & 4 & 4 & 4 \\
\hline 2 & $\begin{array}{l}\text { Intrumen bimbingan konseling yang digunakan } \\
\text { mampu memetakan potensi belajar siswa }\end{array}$ & 4 & 4 & 4 & 4 & 4 & 3 \\
\hline 3 & $\begin{array}{l}\text { Intrumen bimbingan konseling yang digunakan } \\
\text { memudahkan siswa mengenali gaya belajarnya }\end{array}$ & 4 & 4 & 4 & 4 & 4 & 4 \\
\hline 4 & $\begin{array}{l}\text { Intrumen bimbingan konseling yang digunakan } \\
\text { memudahkan siswa mengenali kecerdasan } \\
\text { majemuknya }\end{array}$ & 4 & 4 & 4 & 4 & 4 & 4 \\
\hline \multicolumn{8}{|c|}{ B. Konstruksi } \\
\hline 1 & $\begin{array}{l}\text { Instrumen soal dirumuskan dengan kalimat } \\
\text { singkat dan jelas }\end{array}$ & 4 & 3 & 4 & 4 & 3 & 4 \\
\hline 2 & $\begin{array}{l}\text { Instrumen soal merupakan pernyataan yang } \\
\text { diperlukan saja }\end{array}$ & 4 & 4 & 4 & 4 & 4 & 4 \\
\hline 3 & Terdapat skoring hasil akhir & 3 & 4 & 4 & 3 & 4 & 4 \\
\hline 4 & $\begin{array}{l}\text { Skor penilaian akhir disajikan dalam bentuk } \\
\text { grafik }\end{array}$ & 4 & 4 & 3 & 4 & 4 & 3 \\
\hline \multicolumn{8}{|c|}{ C. Bahasa/Budaya } \\
\hline 1 & Butir soal mnggunakan bahasa yang baku & 4 & 4 & 4 & 4 & 4 & 4 \\
\hline 2 & Instrumen soal bersifat komunikatif & 4 & 3 & 4 & 4 & 3 & 3 \\
\hline 3 & $\begin{array}{l}\text { Tidak menggunakan kata/ungkapan bermakna } \\
\text { ganda. }\end{array}$ & 3 & 4 & 4 & 3 & 4 & 4 \\
\hline 4 & $\begin{array}{l}\text { Tidak menggunakan bahasa yang berlaku } \\
\text { setempat/tabu. }\end{array}$ & 4 & 4 & 3 & 4 & 4 & 3 \\
\hline \multicolumn{2}{|r|}{ Nilai Rerata Total Aspek } & 3,83 & \multicolumn{5}{|c|}{3,86} \\
\hline
\end{tabular}

Berdasarkan hasil penilaian uji kelompok terbatas pada model layanan bimbingan konseling melalui cybercounseling berbasis website didapatkan nilai rerata adalah 3,86. Dengan demikian hasil evaluasi individu oleh 6 siswa yang dapat dilihat pada Tabel 4 menunjukkan bahwa model layanan bimbingan konseling melalui cybercounseling berbasis website yang dikembangkan adalah dalam kategori sangat layak digunakan sebagai model layanan bimbingan konseling berbasis digital.

Dalam masa pandemi Covid-19 pembelajaran di sekolah dengan menerapkan sistem ubiquitos learning yang tidak dapat terhindarkan lagi dengan berbagai platform sosial interaktif penunjang diantaranya adalah: personal computer, PDA, tablet, dan smartphone yang sangat efektif dapat membantu kegiatan belajar mengajar jarak jauh (El Guabassi, Bousalem, Al Achhab, Jellouli, 
\& Mohajir, 2018). Hasil penelitian ini selanjutnya dapat memberikan rekomendasi sekaligus solusi bagi penentu kebijakan pada SMA Muhammadiyah I Taman Kabupaten Sidoarjo guna menerapkan layanan bimbingan konseling berbasis digital. Adapun pertimbangan penentuan SMA Muhammadiyah I Taman Kabupaten Sidoarjo dalam penelitian ini antara lain: 1.) Kesediaan kepala sekolah dalam berkolaborasi menerap-kan model aplikasi cybercounseling berbasis website; 2.) Terpenuhinya fasilitas internet; dan 3.) Antusias dan motivasi guru bagi peningkatan kualitas layanan cybercounseling Islami berbasis website. Waktu pelaksanaan penelitian yakni pada tanggal 15 Juni hingga 15 Agustus 2020. Focus Group Discussion (FGD) dengan para guru bimbingan konseling, guru pendidikan agama Islam, wakil kepala sekolah bidang kurikulum, dan kepala sekolah untuk mengetahui pemahaman layanan cybercounseling Islami berbasis website. Berikut merupakan alur siswa dalam menggunakan layanan bimbingan konseling melalui cybercounseling berbasis website.

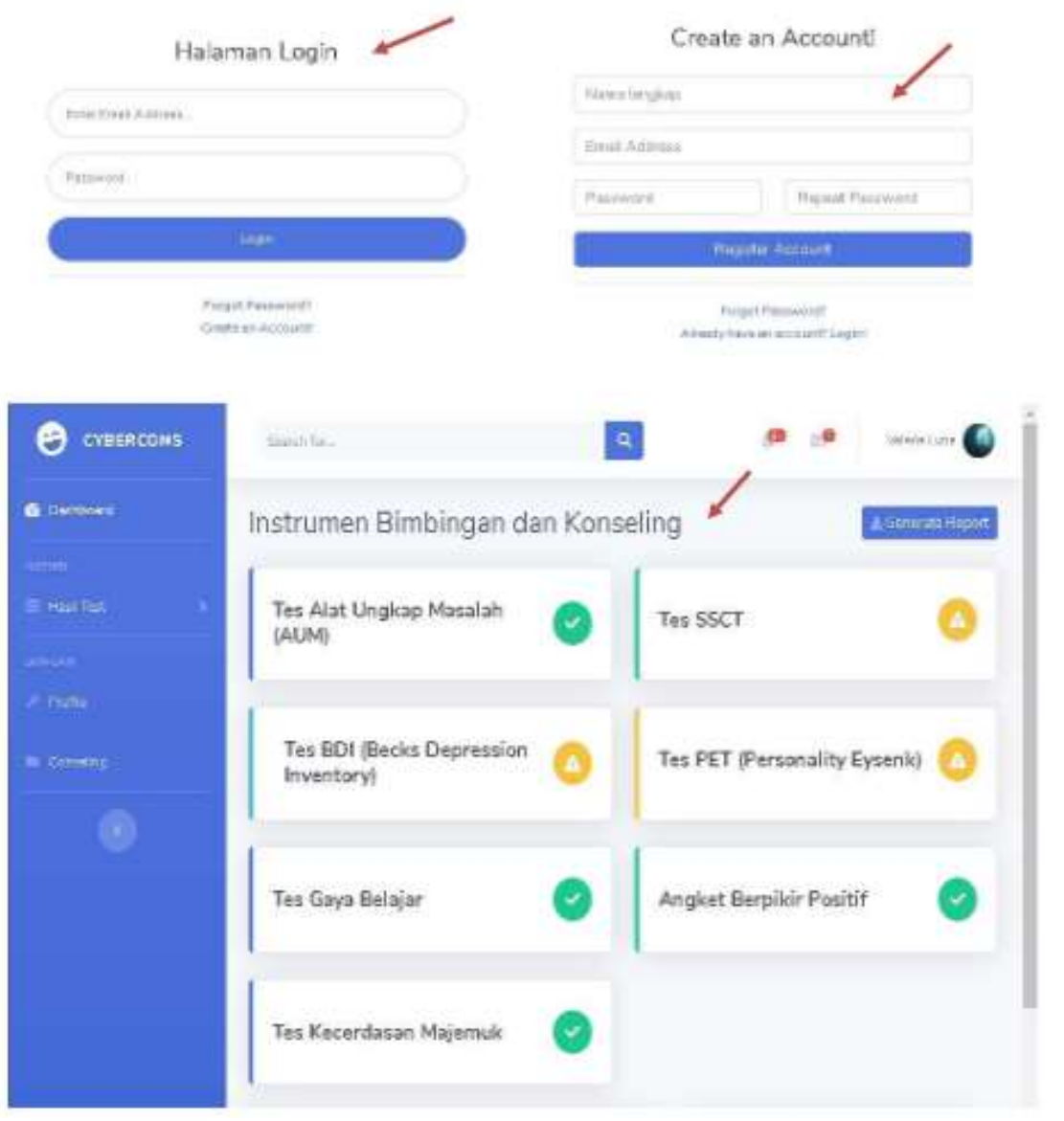

Gambar 2. Model Cybercounseling Berbasis Website

Model layanan bimbingan konseling melalui cybercounseling berbasis website yang dapat dilihat pada Gambar 2 dirancang untuk memberikan kemudahan dalam penyampaian informasi guru kepada siswanya. Hal ini tentu saja dapat menjawab berbagai tantangan pada era revolusi industri 4.0 termasuk model layanan bimbingan konseling yang juga harus mengarah pada internet berbasis cybercounseling (Prasetiawan, 2016). Cybercounseling melibatkan penggunaan media elektronik melalui dunia maya atau online, website, email, dan chat untuk menjaga kerahasiaan kliennya (Petrus \& Sudibyo, 2017). Cybercounseling memungkinkan konselor dan konseling melakukan komunikasi langsung melalui layar monitor tanpa kehadiran fisik diantara keduanya, hal ini akan dapat menghemat jarak dan waktu, serta memberikan layanan ke siswa yang bisa dilaksanakan tanpa batas yakni dimanapun dan kapanpun, guna pencapaian potensi siswanya (Makara-studzi, Golonka, \& 
Izydorczyk, 2019). Tantangan era revolusi industri 4.0 diperlukan perubahan akses layanan bimbingan konseling dengan para siswanya yang terhubung pada internet (Prasetiawan, 2016) atau berbasis cybercounseling (El Guabassi, Bousalem, Al Achhab, Jellouli, \& Mohajir, 2018). Layanan cybercounseling pada penelitian sebelumnya yang dihasilkan adalah layanan cybercounseling yang berbasis email, chat asynchronous, facebook, dan teks menggunakan riliv aplikasi android yang difokuskan pada pemberian layanan bimbingan konseling siswa di sekolah (Kirana, 2019).

\section{Layanan Cybercounseling dalam Membangun Self-Regulated Learning Siswa}

Berdasarkan peraturan Kementerian Pendidikan dan Kebudayaan Republik Indonesia nomor 111 tahun 2014 pada setiap satuan pendidikan baik pada SMP dan SMA diangkat sejumlah konselor atau guru bimbingan dan konseling dengan rasio 1 : 150-160 siswa atau dengan kata lain satu konselor atau guru bimbingan dan konseling melayani 150-160 orang peserta didik. Layanan bimbingan konseling seharusnya merujuk pada pengembangan kurikulum yang telah ditetapkan hal ini berguna untuk meningkatkan critical thinking, communication, collaboration, dan creativity peserta didiknya (Purwadhi, 2019). Dengan demikian diperlukan model pembelajaran dan layanan konseling yang smart (Koper, 2014) berbasis digital (Sari, Ciptadi, \& Hardyanto, 2017), dengan mengutamakan keamanan, kenyamanan, dan privasi siswa (Atif, Mathew, \& Lakas, 2015).

Tabel 5. Hasil Respon Siswa terhadap Penggunaan Cybercounseling Berbasis Website

\begin{tabular}{cllc}
\hline No. & \multicolumn{1}{c}{ Aspek yang dinilai } & \multicolumn{2}{c}{ Prosentase } \\
\hline 1 & Instrumen bimbingan dan konseling mudah dipahami dan dimengerti & $17 \%$ & $83 \%$ \\
2 & Keterbacan tulisannya mudah dipahami & $34 \%$ & $66 \%$ \\
3 & Instrumen bimbingan dan konsling mampu mengukur secara & $24 \%$ & $76 \%$ \\
4 & Sperasional perilaku sehari-hari & $17 \%$ & $83 \%$ \\
5 & $\begin{array}{l}\text { Soal instrumen mencerminkan diri saya sendiri } \\
\text { miliki dan pada memahamanan saya pada bakat, minat yang saya }\end{array}$ & $15 \%$ & $85 \%$ \\
6 & $\begin{array}{l}\text { Mengisi instrumen bimbingan dan konseling menjadikan saya dapat } \\
\text { mengenali potensi diri }\end{array}$ & $16 \%$ & $84 \%$ \\
7 & $\begin{array}{l}\text { Mengisi instrument bimbingan dan konseling menjadikan saya lebih } \\
\text { bersemangat dalam belajar }\end{array}$ & $13 \%$ & $87 \%$ \\
8 & $\begin{array}{l}\text { Instrumen bimbingan dan konseling membantu saya mengenal diri } \\
\text { sendiiri untuk dapat memahami cara belajar yang optimal }\end{array}$ & $21 \%$ & $79 \%$ \\
\hline
\end{tabular}

Hasil respon siswa terhadap penggunaan cybercounseling berbasis website yang dapat dilihat pada Tabel 5 menunjukkan bahwa terdapat hubungan positif yang signifikan antara selfregulated learning dengan peningkatan prestasi belajar siswa. Self-regulated learning yang ditekankan pada penelitian ini antara lain adalah memfasilitasi kesulitan belajar siswa dan mengatasi kebosanan siswa belajar secara online di rumah saja dengan memberikan edukasi berdasar nilai-nilai $\mathrm{Al}$ Qur'an dan hadist untuk siswa agar dapat memahami tugas dan tanggungjawabnya sebagai insan mulia di tengah masa pandemi Covid-19. Dengan siswa mampu memaksimalkan self-regulated learning diharapkan dapat memberikan dampak positif bagi peningkatan hasil belajarnya dan siswa dapat menjalani kehidupannya dengan penuh kebahagiaan dunia dan akhirat.

Self-regulated learning merupakan salah satu variabel penting bagi kesuksesan siswa dalam bidang akademik. Self-regulated learning diperlukan bagi setiap siswa guna menunjang keberhasilannya dalam bidang akademik (Ma arif, 2019). Hasil penelitian menunjukkan bahwa siswa perempuan di SMK memiliki keterampilan self-regulated learning yang lebih baik daripada siswa laki-laki. Siswa membangun self-regulated learning merupakan suatu hal terpenting guna menghindarkan dari perilaku prokrastinasi akademik yang disebabkan kejenuhan selama proses belajarnya. Hasil penelitian ini seyogyanya dapat menjadi dasar bagi guru konselor atau guru bimbingan dan konseling sekolah dalam menyusun program bimbingan dan konseling untuk meningkatkan selfregulated learning dengan memperhatikan karakteristik siswa SMK laki-laki dan perempuan (Saputro, Irwanto, Atun, \& Wilujeng, 2019). Dengan terfasilitasinya siswa pada model layanan 
bimbingan konseling melalui cybercounseling berbasis website akan dapat membantu siswa dalam mendapatkan bantuan bimbingan konseling dimanapun, kapanpun, dan dengan siapapun mereka dapat belajar mengoptimalkan potensi yang dimilikinya. Media pembelajaran digital terbukti efektif mampu mengoptimalkan hasil belajar siswa dengan sistem yang mampu mengintegrasikan permasalahannya dengan realitas sosial yang terjadi (Fahyuni, Wasis, Bandono, \& Arifin, 2020).

\section{SIMPULAN}

Membangun lingkungan belajar di sekolah yang smart guna mengoptimalkan hasil belajar siswanya merupakan cita-cita bersama. Hal ini dikarenakan tantangan era revolusi industri 4.0 yang semakin berkembang pesat, oleh karenanya diperlukan perubahan akses layanan bimbingan konseling yang dapat dihubungkan pada internet. Cybercounseling merupakan layanan bimbingan dan konseling berbasis digital dalam bentuk website, email, serta chat untuk menjaga kerahasiaan dari kliennya. Dengan adanya layanan berbasis cybercounseling memungkinkan guru bimbingan dan konseling melakukan komunikasi langsung melalui layar monitor tanpa kehadiran fisik diantara keduanya, hal ini akan dapat menghemat jarak dan waktu, serta memberikan layanan ke siswa yang bisa dilaksanakan tanpa batas yakni dimanapun dan kapanpun guna pencapaian potensi siswanya. Temuan dari penelitian dan pengembangan ini menunjukkan bahwa terdapat hubungan positif yang signifikan antara self-regulated learning dengan peningkatan prestasi belajar siswa. Self-regulated learning yang ditekankan pada penelitian ini antara lain memfasilitasi kesulitan belajar siswa dan kebosanan siswa belajar daring di rumah saja dengan memberikan edukasi berdasar nilai-nilai Al Qur'an dan hadist untuk siswa dapat memahami tugas dan tanggungjawabnya sebagai insan mulia di tengah masa pandemi Covid-19. Dengan siswa mampu memaksimalkan self-regulated learning diharapkan dapat memberi dampak positif bagi peningkatan hasil belajarnya dan siswa menjalani kehidupannya dengan penuh kebahagiaan dunia dan akhirat.

\section{DAFTAR PUSTAKA}

Aliem, N., Sugiharto, D. Y. P., \& Awalya, A. (2019). Group counseling with cognitive restructuring technique to improve the self-efficacy and assertiveness of students who experienced advanced study anxiety. Jurnal Bimbingan Konseling, 8(4), 106-112. Retrieved from https://journal.unnes.ac.id/sju/index.php/jubk/article/view/29803/13164

Atif, Y., Mathew, S. S., \& Lakas, A. (2015). Building a smart campus to support ubiquitous learning. Journal of Ambient Intelligence and Humanized Computing, 6(2), 223-238. doi: https://doi.org/10.1007/s12652-014-0226-y

Bahiyah, L., Sudarmin, S., \& Hartono, H. (2019). Analysis of Students Metacognitive Skill in Solving Problem on Guided Inquiry Learning Model. Journal of Innovative Science Education, 8(3), 248-254.

Chan, H. C., \& Chan, L. (2018). Smart library and smart campus. Journal of Service Science and Management, 11(6), 543-564. doi: https://doi.org/10.4236/jssm.2018.116037

Dick, W., Carey, L., \& Carey, J. O. (2009). The systematic design of instruction (5 ${ }^{\text {th }}$ ed.). New Jersey: Pearson Education.

El Guabassi, I., Bousalem, Z., Al Achhab, M., Jellouli, I., \& Mohajir, B. E. E. (2018). Personalized adaptive content system for context-aware ubiquitous learning. Procedia Computer Science, 127, 444-453. doi: https://doi.org/10.1016/j.procs.2018.01.142

Fahyuni, E. F., Wasis, W., Bandono, A., \& Arifin, M. B. U. B. (2020). Integrating Islamic values and science for millennial students' learning on using seamless mobile media. Jurnal Pendidikan IPA Indonesia, 9(2), 231-240. doi: https://doi.org/10.15294/jpii.v9i2.23209

Fahyuni, E. F. (2018). Bimbingan dan konseling Islami di sekolah. Sidoarjo: Universitas Muhammadiyah Sidoarjo Press. 
Haryani, S., Masfufah, M., Wijayati, N., \& Kurniawan, C. (2018). Improvement of metacognitive skills and students' reasoning ability through problem-based learning. Journal of Physics: Conference Series, 983(1), 012174. doi: https://doi.org/10.1088/1742-6596/983/1/012174

Hernawati, L., Sugiarto, D. Y. P., Purwanto, E., \& Awalya, A. (2018, September). The effectiveness of cyber counseling service to enhance student performance in statistics. In International Conference on Science and Education and Technology 2018 (ISET 2018). Atlantis Press. doi: https://doi.org/10.2991/iset-18.2018.63

Kirana, D. L. (2019). Cyber counseling sebagai salah satu model perkembangan konseling bagi generasi milenial. Al-Tazkiah : Jurnal Bimbingan dan Konseling Islam, 8(1), 51-63. doi: https://doi.org/10.20414/altazkiah.v8i1.1101

Koper, R. (2014). Conditions for effective smart learning environments. Smart Learning Environments, 1(1), 1-17. doi: https://doi.org/10.1186/s40561-014-0005-4

Ma`arif, M. A. (2019). Internalisasi nilai multikulutural dalam mengembangkan sikap toleransi ( Studi di Pesantren Mahasiswa Universitas Islam Malang). Nazhruna: Jurnal Pendidikan Islam, 2(1), 164-189. doi: https://doi.org/10.31538/nzh.v2i1.179

Makara-Studzińska, M., Golonka, K., \& Izydorczyk, B. (2019). Self-efficacy as a moderator between stress and professional burnout in firefighters. International Journal Of Environmental Research and Public Health, 16(2), 183. doi: https://doi.org/10.3390/ijerph16020183

Marzuki, M., \& Haq, P. I. (2018). Penanaman nilai-nilai karakter religius dan karakter kebangsaan di Madrasah Tsanawiyah Al Falah Jatinangor Sumedang. Jurnal Pendidikan Karakter, 8(1), 84-94. doi: https://doi.org/10.21831/JPK.V8I1.21677

Nikolov, R., Shoikova, E., Krumova, M., Kovatcheva, E., Dimitrov, V., \& Shikalanov, A. (2016). Learning in a smart city environment. Journal of Communication and Computer, 13, 338350. doi: https://doi.org/10.17265/1548-7709/2016.07.003

Kementerian Pendidikan dan Kebudayaan Republik Indonesia. (2014). Peraturan Menteri Pendidikan dan Kebudayaan Republik Indonesia Nomor 111 Tahun 2014 tentang Bimbingan dan Konseling pada Pendidikan Dasar dan Pendidikan Menengah.

Petrus, J., \& Sudibyo, H. (2017). Kajian konseptual layanan cyberconseling. Konselor, 6(1), 6-12. doi: https://doi.org/10.24036/02017616724-0-00

Prasetiawan, H. (2016). Cyber counseling assisted with Facebook to reduce online game addiction. Guidena: Jurnal Ilmu Pendidikan, Psikologi, Bimbingan dan Konseling, 6(1), 28-32. doi: https://doi.org/10.24127/gdn.v6il.409

Purwadhi, P. (2019). Pengembangan kurikulum dalam pembelajaran abad XXI. Mimbar Pendidikan, 4(2), 103-112. doi: https://doi.org/10.17509/mimbardik.v4i2.22201

Purwanto, A., Pramono, R., Asbari, M., Hyun, C. C., Wijayanti, L. M., \& Putri, R. S. (2020). Studi eksploratif dampak pandemi Covid-19 terhadap proses pembelajaran online di Sekolah Dasar. EduPsyCouns: Journal of Education, Psychology and Counseling, 2(1), 1-12. Retrieved from https://ummaspul.e-journal.id/Edupsycouns/article/view/397/223

Rahayu, R. (2018). Peran guru PAI, wali kelas, dan konselor BK dalam pembinaan perilaku keberagamaan dan dampaknya terhadap akhlak siswa: Penelitian di SMP Darul Hikam Bandung (Unpublished doctoral dissertation). Universitas Islam Negeri Sunan Gunung Djati Bandung, Indonesia.

Rosito, A. C. (2018). Kepribadian dan self-regulated learning. Jurnal Psikologi, 45(3), 189-199. doi: https://doi.org/10.22146/jpsi.28530

Saputro, A. D., Irwanto, I., Atun, S., \& Wilujeng, I. (2019). The impact of problem solving instruction on academic achievement and science process skills among prospective 
104 - Jurnal Inovasi Teknologi Pendidikan

elementary teachers. Elementary Education Online, 18(2), 496-507. doi: https://doi.org/10.17051/ilkonline.2019.561896

Spector, J. M. (2016, March). Smart learning environments: Concepts and issues. In Society for Information Technology \& Teacher Education International Conference (pp. 2728-2737). Association for the Advancement of Computing in Education (AACE). Retrieved from https://www.learntechlib.org/primary/p/172078

Surtiyoni, E. (2018). Pengembangan layanan bimbingan kelompok berbasis nilai-nilai ajaran Islam untuk meningkatkan tanggung jawab siswa. Edudikara: Jurnal Pendidikan dan Pembelajaran, 3(1), 32-42. doi: https://doi.org/10.32585/edudikara.v3i1.76

Sutijono, S., \& Farid, D. A. M. (2018). Cyber Counseling di Era Generasi Milenial. Sosiohumanika: Jurnal Pendidikan Sains Sosial dan Kemanusiaan, 11(1), 19-32. doi: https://doi.org/10.2121/sosiohumanika.v11i1.1000

Sari, M. W., Ciptadi, P. W., \& Hardyanto, R. H. (2017). Study of smart campus development using internet of things technology. IOP Conference Series: Materials Science and Engineering, 190(1), 012032. doi: https://doi.org/10.1088/1757-899X/190/1/012032

Zainudin, Z. N., \& Yusof, Y. M. (2018). Gender comparisons on the cyber-counseling and face-toface counseling approaches. International Journal of Academic Research in Business and Social Sciences, 8(8), 677-684. doi: https://doi.org/10.6007/ijarbss/v8-i3/3992 